\title{
Laboreal
}

Volume $16 \mathrm{~N}^{\circ} 2$ | 2020

Programa de Pesquisa do Curso da Ação

\section{Pandemias e (des)encontros com o trabalho}

Pandemias y (des)encuentros con el trabajo

\section{Liliana Cunha}

\section{(2) OpenEdition}

Journals

\section{Edição electrónica}

URL: https://journals.openedition.org/laboreal/17408

DOI: 10.4000/laboreal.17408

ISSN: 1646-5237

\section{Tradução(ões):}

Pandemias y (des)encuentros con el trabajo - URL : https://journals.openedition.org/laboreal/17412

[es]

\section{Editora}

Universidade do Porto

\section{Refêrencia eletrónica}

Liliana Cunha, «Pandemias e (des)encontros com o trabalho», Laboreal [Online], Volume 16 N² | 2020, posto online no dia 01 décembre 2020, consultado o 28 juin 2022. URL: http://

journals.openedition.org/laboreal/17408; DOl: https://doi.org/10.4000/laboreal.17408

Este documento foi criado de forma automática no dia 14 dezembro 2020.

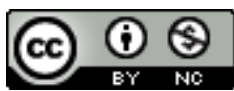

Laboreal está licenciado com uma Licença Creative Commons - Atribuição-NãoComercial 4.0 Internacional. 


\title{
Pandemias e (des)encontros com o trabalho
}

Pandemias y (des)encuentros con el trabajo

\author{
Liliana Cunha
}

1 Os dois textos que nos dá a ler a rubrica Datário deste número de Laboreal assinalam na sua reflexão o acontecimento talvez mais marcante das nossas vidas coletivas, em 2020 - a crise sanitária por Covid-19.

2 A arqueologia do conhecimento sobre esta pandemia e os seus impactos encontra-se em construção, e em movimento no tempo. Permanece em aberto o alcance de todo o seu devir histórico. Mas, que história podemos/queremos construir ? Qual o lugar e que encontros com o trabalho reserva esta história?

\section{Encontros produzidos pela crise pandémica com o trabalho}

3 Os indicadores de análise da pandemia têm evoluído para a melhor compreender. Começam a desvelar-se, mas estamos ainda a apreendê-los.

4 Apesar da ausência do trabalho nas estatísticas oficiais - com dados discriminados, por exemplo, por profissão, estatuto de emprego, condições de trabalho -, manifesta em vários países da UE (ETUI, 2020), a sua referência impõe-se. As relações entre o trabalho, o território, e o Bem Comum encontram, no cenário atual de crise, um espaço de visibilidade sem precedentes.

5 Podemos falar, a título de exemplo, da emergência de surtos em alguns contextos de trabalho, ou em determinados clusters industriais, onde a atividade laboral tem sido mantida - como foi o caso, em Portugal, mais recentemente, das restrições à mobilidade impostas nos concelhos de Felgueiras, Lousada e Paços de Ferreira, a que não será alheio o facto de estes serem territórios de forte expressão de atividade industrial - no setor do calçado, do vestuário, e do mobiliário, respetivamente. Mas, também, dos exemplos de empresas e de trabalhadores/as que reorientaram a sua atividade para dar 
resposta às necessidades locais de equipamentos de proteção individual dos profissionais de saúde (o caso de uma empresa de bebidas que fez uso do álcool da produção de cerveja para a produção de álcool gel para as mãos, ou de empresas têxteis, que passaram a produzir batas e máscaras, para citar só alguns exemplos). São microiniciativas que transformam as trocas, os debates, as interações no e pelo trabalho (Coutarel \& al., 2020). Não resultam da ação política, mas protagonizam um verdadeiro debate com o Bem Comum.

Estes diferentes tipos de encontros produzidos pela crise pandémica com o trabalho desde a sua conceção como fonte de contaminação, à sua afirmação como atividade social - revelam como o seu compromisso na gestão da vida coletiva é feito de escolhas e de criação de alternativas. Face às normas estritas da gestão pelo mercado, que margem de manobra foi e é reservada ao debate sobre a evolução dos usos de si no trabalho (Schwartz, 2020), à organização do trabalho, e à sua redefinição face aos horizontes da vida social?

7 Esta é uma questão central que releva do contributo do texto de Jairo Luna e Maurício Torres Tovar. A par de uma referência específica à realidade colombiana, os autores situam estas questões no plano mais global, como se partes da história de evolução desta pandemia se repetissem, e encontrassem eco em diferentes geografias.

\section{Um outro diálogo com o trabalho para além das urgências do presente}

8 Desde o início da crise pandémica, um legado de novos termos passou a entrar em circulação na linguagem coletiva. Fala-se de serviços ditos "essenciais"; de profissionais da "linha da frente" ; ... E fala-se muito mais de teletrabalho [1].

O seu uso já normalizado não é isento de ambiguidade. O reconhecimento público de algumas atividades profissionais ditas agora "essenciais" é paradoxal face às condições de trabalho e de emprego dos/as seus/as protagonistas - atividades ocupadas frequentemente por mulheres, enquadradas em segmentos de emprego mais frágeis, com estatutos precários (ILO, 2020), sob maior ameaça de descontinuidade do percurso profissional, em condições que pouco permitem negociar formas de organização do trabalho alternativas.

Mesmo estando "na linha da frente", o conhecimento que temos do real da atividade de muitos/as destes/as trabalhadores/as não desvanece as fronteiras entre o visível e o invisível. 0 acesso ao que está por detrás desta "linha invisível", requer a escuta do seu ponto de vista, e dos debates que atravessam as suas atividades de trabalho.

11 Ora, as medidas de prevenção definidas, seguindo uma abordagem essencialmente higienista, prescritas na maioria dos casos em total desaderência face ao real do trabalho, sem consulta e sem negociação com os que exercem a atividade face às exigências que ela impõe, revelam-se claramente insuficientes ou inaplicáveis. E a imposição destas medidas de forma transversal, não nos permite saber, ainda assim, como estão a ser reapropriadas nos locais de trabalho.

12 Esta invisibilidade é também patente junto daqueles que se mantêm em regime de teletrabalho. Como se faz a avaliação de riscos nessas situações? Se os riscos associados ao trabalho permanecem, neste caso, na esfera privada, fica a sua gestão sob o ónus da responsabilidade de cada um? 
de determinados direitos e da ação coletiva, como discute o texto de Jairo Luna e Maurício Torres Tovar, faz antecipar alguns dos impactos que a crise pandémica atual começa a revelar. Ao mesmo tempo, a atividade não pode ser subtraída desta análise, sob pena de se subdimensionar os seus debates, e de se atribuir um estatuto residual às alternativas que propõe, atuais ou potenciais.

\section{A história repete-se... mas, pode ser reescrita}

Pensar o futuro pós-pandemia, supõe que a sua aprendizagem faça história. O que aprendemos com outras pandemias ? Há um lugar para o trabalho na história de outras pandemias ? Foi este o mote da reflexão do texto de Maria da Luz Sampaio, a partir de uma incursão na última pandemia, de 1918/19 - a "Pneumónica" -, como é conhecida em Portugal.

A história de cada pandemia e das vidas que ela atravessa é, claro, sempre singular, e não se compadece com nenhum tipo de comparações, de nenhum tipo. A falta de dados sobre a relação entre a crise sanitária da altura (há cem anos atrás !) e o trabalho não nos surpreende, talvez.

Mas, não será o momento atual oportuno para repensar a delimitação entre as questões de saúde no trabalho e de saúde pública? Para pensar a prevenção numa lógica mais compreensiva, do que prescritiva, reconhecendo que as normas de segurança, e designadamente o uso de EPI, não podem ser perspetivadas em exterioridade face às situações concretas de trabalho ? Para convocar o trabalho e os seus atores na conceção do futuro?

Nesta rubrica "Datário", não se procura contar a História como sobrevoando a vida de cada um/a, sem que cada um/a possa dela tomar parte. E o apelo permanece: reivindicar o lugar do trabalho na história desta pandemia, e do seu contributo para o que dela podemos apre(e)nder.

\section{BIBLIOGRAFIA}

Coutarel, F. Pueyo, V., Lacomblez, M., Delgoulet, C., Barthe, B., Poète, V., Garrigou, A., Dugué, B., Blatter, C., Grunstein, A., Liehrmann, E., Michez, B., Negroni, P., \& Thomas, C. (2020). Crisis sanitaria y crisis del trabajo : ¿una oportunidad en el caos ? Sociología del Trabajo, 17-21, https:// doi.org/10.5209/stra.70687

ILO (2020). The COVID-19 response : Getting gender equality right for a better future for women at work. Geneva : International Labour Office. https://www.ilo.org/wcmsp5/groups/public/--dgreports/--gender/documents/publication/wcms_744685.pdf

ILO-Eurofound (2017). Working anytime, anywhere : the effects on the world of work. Luxembourg: Publications Office of the European Union and Geneva : International Labour Office https:// www.eurofound.europa.eu/publications/report/2017/working-anytime-anywhere-the-effectson-the-world-of-work

Laboreal, Volume $16 \mathrm{~N}^{\circ} 2$ | 2020 
Schwartz, Y. (2020). Activité(s) et usages de soi : quel(s) 'milieux' pour l'humain ? Les Études philosophiques, 201, 93-123. https://www.cairn.info/revue-les-etudes-philosophiques-2020-1page-93.htm

\section{NOTAS}

1. O teletrabalho não é tributário desta pandemia, como é notado pelo Acordo-Quadro Europeu sobre Teletrabalho, de 16 de julho de 2002 (ILO-Eurofound, 2017), pese embora a sua maior expressão seja dela efeito.

\section{AUTOR}

\section{LILIANA CUNHA}

Faculdade de Psicologia e de Ciências da Educação da Universidade do Porto. Centro de Psicologia da Universidade do Porto, Rua Alfredo Allen s/n , 4200-135 Porto, Portugal lcunha@fpce.up.pt 